\title{
Rajasthani traditional headgear: Protection to sophistication
}

\author{
Shikha Dashora and Meenu Srivastava
}

Received: 09.09.2019; Accepted: 28.11.2019

See end of the paper for authors' affiliations

Meenu Srivastava

Department of Textiles and Apparel Designing, College of

Community and Applied Science, Maharana Pratap University of Agriculture and Technology,

Udaipur (Rajasthan) India

Email : meenuclt@yahoo.com
ABSTRACT : Rajasthan is very popular in all over the world for its cultural diversity, tradition and antique handicraft. Rajasthani costumes show its own uniqueness, out of which headgear, traditional male costume is a great identification mark of belongingness from Rajasthan. This paper deals with the protection and utilization of turban and socio-cultural significance of headgear. The headgear used in Rajasthan to protect the head from extraordinary climatic condition as well as it plays an important role in identify culture, caste, religion and belongingness. It is the symbol of status. It was the most important part of nobleman's costume and their courtier. Most of the Rajasthani community are very much attached to this attire as their social and cultural heritage.

KEY WORDS: Handicraft, Jewelleary, Rajasthani costumes, Block printing

- HOW TO CITE THIS PAPER : Dashora, Shikha and Srivastava, Meenu (2019). Rajasthani traditional headgear: Protection to sophistication. Asian J. Home Sci., 14 (2) : 463-467, DOI: 10.15740/HAS/AJHS/ 14.2/463-467. Copyright@ 2019: Hind Agri-Horticultural Society. 